\title{
THE SOFT POWER AS A POTENTIAL TOOL OF INTERNATIONAL POLICY OF THE KINGDOM OF SAUDI ARABIA
}

\begin{abstract}
The soft power is an effective weapon that allows to achieve goals through persuasion rather than coercion or the use of hard power that may have high costs and heavy losses to humanity. This paper investigates some of the most important reasons for using soft power to build optimal relationships in international relations by the Kingdom of Saudi Arabia. The purpose is to provide the most significant components of soft power for the Kingdom of Saudi Arabia and the best way to use it, especially against those who seek expansion and spread the ideology of religious extremism and create terrorist militias in neighboring countries that carry out proxy wars to serve their expansion goals.
\end{abstract}

KEYWORDS: soft power, hard power, resources evolution, strategic employment, the Kingdom of Saudi Arabia

\section{SOFT POWER JAKO POTENCJALNE NARZĘDZIE POLITYKI MIĘDZYNARODOWEJ KRÓLESTWA ARABII SAUDYJSKIEJ}

\begin{abstract}
ABSTRAKT: Soft power jest skuteczną bronią, która pozwala osiągać cele poprzez perswazję, a nie przymus lub użycie twardej siły (hard power), która może wiązać się z wysokimi kosztami i dużymi stratami dla ludzkości. Niniejszy artykuł analizuje niektóre z najważniejszych powodów wykorzystywania miękkiej siły do budowania optymalnych stosunków w relacjach międzynarodowych przez Arabię Saudyjską. Celem jest zapewnienie Królestwu Arabii Saudyjskiej najważniejszych elementów miękkiej siły i jak najlepszego ich wykorzystania, zwłaszcza wobec tych, którzy dążą do ekspansji i szerzenia ideologii ekstremizmu religijnego oraz tworzą w sąsiednich krajach milicje terrorystyczne, które prowadzą wojny zastępcze w celu ekspansji.
\end{abstract}

SŁOWA KLUCzowe: soft power, hard power, ewolucja zasobów, zatrudnienie strategiczne, Królestwo Arabii Saudyjskiej

\section{INTRODUCTION}

The strength of values and principles is part of what is currently called soft power, and that power, together with coercion (hard power), are the final criterion for the comprehensive power of the state. The influence of this power has expanded with the increase in human technological development, scientific knowledge, and the rapprochement of previously 
antagonistic national forces. Just as a party desiring to achieve its international goals cannot succeed in its endeavours unless it possesses the components of comprehensive strength with respect to both types of power (soft and hard), on the other hand, the lack of these components or either one of them, makes it weak and deprived of the will to protect itself. This international reality is faced by all countries, including those of the Middle East, which requires the active forces in this region to focus on building their strength in possessing both powers (soft and hard), if they want to protect themselves and their citizens from the influence of others, and play an effective role in the international theatre ${ }^{1}$.

Soft power is a concept coined by Joseph Nye (1990) of Harvard University. The author describes it as the ability to attract and persuade without coercion or the use of force. Recently, this term has been used to describe the influence and change of social and public opinion through less transparent channels and the lobbying of political and non-political organisations. Nye said that with soft power, "the best propaganda is not propaganda", and explained that in the information age "credibility is the rarest resource". The concept of power is one of the basic concepts of political science. Researchers and those who are interested in international relations do not clarify on the power being the primary ruler of relations between states ${ }^{2}$. The definition of power is perceived differently among researchers due to the complex nature of the concept ${ }^{3}$.

Power can be defined as the ability to influence the behaviour of others, to obtain desired results or to impose control over them. However, the essence of the concept, as stated by Carl Friedrich Gauss, is the creation of a subordinate relationship between two parties through which the first party can make the second party do what they want and specifically to act in a way that augments the interests of the possessor of power. Austin Rabini also defined power as the relationship of subordination and obedience on the one hand, and the relationship of authority and control on the other ${ }^{4}$. We use reward and persuasion, and then if that does not work, we often adopt coercion and violent force.

The power of the state is considered one of the factors, which is attached special importance in the field of international relations. Moreover, having this power, the state plays a significant role in the international community. It also defines the framework of its relations with external forces in the international environment, so that possessing the elements of power is not even sufficient. When the state would like to be influential, it must adopt effective force policies. Power is the ability to allow others to do things they would not do if it was not for the influence of the power they received. Until Joseph Nye developed this concept of power, it was

\footnotetext{
${ }^{1}$ J.P. Wagner, The Effectiveness of Soft \& Hard Power in Contemporary International Relations. E-International Relations, 2014, pp. 1-5, https://www.e-ir.info/2014/05/14/the-effectiveness-of-soft-hard-power-incontemporary-international-relations/ (13.05.2021).

${ }^{2}$ M. Górnikiewicz, R. Bielawski, M. Walkowiak, Russian "Hard Power" and "Soft Power” in Influencing Central and Eastern European Countries on the Example of Poland in the COVID-19 Era, "International Journal of Economics and Business Administration" Vol. VIII, Iss. 3, 2020, pp. 18-26.

${ }^{3}$ K. Holsti, The Concept of Power in the Study of International Relations, "Background" 7(4) 1964, p. 179.

${ }^{4}$ G. Satell, Our World Turned Upside Down Digital Tonto, 2011, https://digitaltonto.com/2011/our-world-turnedupside-down/ (13.05.2021).
} 
associated with coercive practices, which compel others to act in a certain way. As for the concept of soft power, it opens the door to study the ability to influence the behaviour of others through attraction and containment rather than coercion ${ }^{5}$.

Soft power is the strength of the model, the attractiveness of culture, the transcendence of values and principles, and the credibility that results from adhering to all of this. It is the characteristics that make others admire the country as a role model and source of inspiration. Soft power is the ability to influence others so that what you want becomes what they want, and it means your values, your culture, your principles, and your way of life become the model that they want to follow ${ }^{6}$. The spread of fast food brands from the US to the rest of the world is a good example of national soft power. The fact that people around the world are attracted to American jeans is another soft power case. Denmark's reputation as the least corrupt country in the world is also soft power ${ }^{7}$. The known subtlety of Swiss society is a force of soft power as well. In addition, the amazing urban development in Dubai and the rigorous administrative efficiency in the United Arab Emirates (UAE) is another case. We may understand soft power as the opposite of hard power in its military and economic dimensions, and we may understand it as the third side of the power triangle, which includes coercive power, power of reward, power of inspiration, Objective Equations of Military Power, economic power, cultural power, and ethics ${ }^{8}$.

The use of force in the international system is the ability of some political actors to use or threaten to deploy armed forces to impose their will on other actors, whether to force them to do certain things or to prevent others from doing it. However, this concept developed after the Second World War due to the severe damage of the world as a result of this conflict, and the role of military force or the threat of it in the relations between countries became very small compared to the economic power. For example, in the conflict between capitalism and socialism, each side attempted to win over several countries by economic power. However, after the fall of the Berlin Wall, the transformation of the world into a unipolar one, the spread of globalisation, another type of force emerged to influence international relations, and it was the soft power. This means the ability to shape the preferences of others, and if we assume that there is a relationship between two parties, the first party can influence the second party by directing its behaviour; this is done by presenting attractive culture and values to the other party rather than bribery, threat, or coercion ${ }^{9}$.

\footnotetext{
${ }^{5}$ J. Nye, Soft Power, "Foreign Policy" (80) 1990, p. 153.

${ }^{6}$ G. Gallarotti, Soft power: what it is, why it's important, and the conditions for its effective use, "Journal of Political Power" 4(1) 2011, pp. 25-47.

7 J. Mcclory, A Global Ranking of Soft Power, 2019, pp. 37-63, https://softpower30.com/wpcontent/uploads/2019/10/The-Soft-Power-30-Report-2019-1.pdf

${ }^{8}$ E. Ketbi, Contemporary Shifts in UAE Foreign Policy: From the Liberation of Kuwait to the Abraham Accords, "Israel Journal of Foreign Affairs" 14(3), 2020, pp. 391-398.

${ }^{9}$ M. Howard, The Strategic Approach to International Relations, "British Journal of International Studies" 2(1), 1976, pp. 67-75.
} 


\section{RESEARCH METHODOLOGY}

The research question was formulated as following: Can the soft power be a potential, effective tool, which will support achieving goals within the international policy of the Kingdom of Saudi Arabia? According to that question, the author has used empirical and theoretical research methods such as: literature review, analysis, synthesis, comparison, and deduction (with inference methods). It allows to collect empirical data first, then using analysis and comparison to obtain complex knowledge. And then by synthesizing and deducing, the author reached the final conclusions, receiving the answer to the research question. In the final stage, the author discusses the results with other experts in this field from the Kingdom of Saudi Arabia, and after a final check and corrections, he has completed the paper.

\section{The ConcePt OF Soft Power AND Its Resources Evolution}

Joseph Nye was considered the first one to formulate the concept of soft power in the form of a convincing and well-constructed theory. However, before Nye proposed his theory, soft power has appeared throughout human history. However, it first appeared in the form of a theory in the 20th century. It was formulated by the Italian philosopher and thinker, Antonio Gramsci, in his theory of cultural hegemony in his important book (Prison Letters 1926-1934). According to Gramsci, the general public is subject to the capitalist elite that controls their minds and ensures that they do not deviate from the context of capitalist society. France was the first country to adopt this concept via the cultural influence of its colonies. Education aimed to create a good image of French society in its colonies, while spreading its language throughout them. Britain and America also promoted principles consistent with the nature of their economic systems to serve their interests, since liberalism and democracy are closely aligned with capitalism and freedom of trade. President Woodrow Wilson during his presidency (19131921) transformed the use of soft power that were based on peace and the rebuilding of Europe after World War I, but this did not prevent the outbreak of World War II ${ }^{10}$.

Joseph Nye introduced the theory of soft power after the fall of the Soviet Union. It was used by the US extensively to emphasise the unipolar system and to spread the values of freedom, democracy, and human rights. It also played an important part in the US's war against Iraq in 2003, restoring the widespread use of the concept of soft power in international relations. Along with this deployment of soft power, "the Greater Middle East" document appeared, which the United States presented to the G8 in 2004. In this context, the revolution of the Arab Spring was an example of soft power. A group within a society was able to highlight the

\footnotetext{
${ }^{10}$ T. Bates, Gramsci and the Theory of Hegemony, "Journal of The History of Ideas" 36(2), p. 351.
} 
corruption of the regime and guide the people through media and technology to exert pressure that led to their downfall without direct military intervention ${ }^{11}$.

Soft power is an indirect, compulsory, binding, mental and ethical debate aimed at influencing public opinion inside and outside the country. Accordingly, it is directed towards domestic and foreign countries. Its main goal is to influence, to control and to create an indirect obligation. The French Michel Foucault (1926-1984) observed that soft power had a great influence on public opinion, and Joseph Nye agreed with it. However, Nye excluded economic means as one of the forms of soft power in terms of influence. The definitions confirmed that soft power affects non-violent means of control and the domination of minds ${ }^{12}$.

Soft power also has significant effects on economic development by promoting local economies, supporting investments and local tourism, highlighting scientific, technical, cultural, and economic achievements, and by opening communication channels. Because of its nature that differs from hard (physical) power, soft power depends more on components than the hard power. The use of military force, which is the ultimate tool to impose influence, requires decisions from official institutions such as parliaments, governments, and army leaders. However, the use of soft power no longer requires reliance on governments and official institutions. Instead, it depends more on non-governmental bodies and institutions such as civil society organisations, as well as multinational companies and even individuals ${ }^{13}$.

\section{The IMPortance OF Soft PoWer}

The importance of soft power is expressed in the fact that it can affect production and thus enhance the economic power of the countries associated with it, increasing their influence and political efficiency on the world map and decision-making centres. Soft power should never be underestimated. Many countries have noticed its usefulness and how it can be turned into a key to economic growth and effective political impact ${ }^{14}$.

\section{THe Role OF Soft POWER IN TOURISM}

Soft power can attract tourists and revive a country's tourism industry by promoting its artistic or cultural channels. Some countries have succeeded in reaching large segments of foreign tourists through their films or soap operas. Turkey is one of the countries that has been able to promote tourism by dubbing series and last year the local report by Daily Sabah indicated that Turkish TV series came second in the world rank after the $\mathrm{US}^{15}$.

\footnotetext{
${ }^{11}$ B. Ozgun Erler, Challenges for EU in the Middle East: Use of Soft Power, "Studia Europejskie-Studies in European Affairs", 2, 2016, pp. 9-19.

${ }_{12}$ M. Behrent, Foucault and Technology, "History and Technology" 29(1), 2013, pp. 54-104..

${ }^{13}$ T. Harris, Foreign policy in an age of austerity: 'soft power', hard choices, "Observatoire De La Société Britannique" (20), 2018, pp. 17-36.

${ }^{14}$ G. Gallarotti, Soft power: what it, op. cit.

${ }^{15}$ C. Ooi, Soft power, tourism, Encyclopedia of Tourism, 2015, pp. 1-2.
} 
Modern communication technology has helped individuals break down the geographical barriers, which hindered their ability to communicate. As a result, individuals from different countries and regions have formed networks of acquaintances and conversation, so that individuals are able to form awareness far away from the influences of official media, or at least away from the influence of official institutions (whatever that says about the independence of traditional media organizations). Therefore, individuals play more important roles in influencing others' perceptions of local politics in their countries, and this viewpoint strongly contributes to the perception of the country's strength, its government, or the rationale and correctness of its policies ${ }^{16}$.

Nevertheless, traditional institutions remain a component of soft power in terms of efficiency and effectiveness of performance, rather than in terms of size or wealth. The most important elements of soft power related to official institutions include the efficiency, effectiveness, and skills of diplomacy, as well as official institutions' public relations in trade, culture, and sports, which includes the organisation of festivals, exhibitions, and competitions as well as the encouragement of innovation, invention, research, and advanced technological applications ${ }^{17}$.

Likewise, the sources of soft power include historical components, such as history and the Pharaonic civilisation in Egypt, and similar ancient cultures such as Greece, China, and India. From this perspective, it can be stated that a country such as the Kingdom of Saudi Arabia in international politics, economy, culture, and society can play a prominent role in achieving influence and substantial soft power. At the economic level in particular, the Kingdom is considered a source of strength, especially after joining the G20 and taking the presidency in this session, which makes it one of the largest economies in the world and places it firmly in the eyes of the world, with many countries seeking to establish long-term partnerships and investments with it. At the social level, the Kingdom is considered one of the countries that most frequently interacts with modern media. Moreover, on the technical level, it is ahead of many countries in terms of being known for tourism and ease of granting investment visas for many countries all over the world, including citizens of the Republic of Poland ${ }^{18}$.

Accordingly, the sources of soft power are divided into qualitative human components such as the ability and tendency to socialise with others, into specific and institutional foundations, and into technological, cultural, historical and natural foundations. The use of soft power generally requires patience and communication in planning and implementation, rather than disruption. Due to the nature of the sources of soft power, it takes longer to obtain the

\footnotetext{
${ }^{16}$ M. Blok, E. van Ingen, A. de Boer, M. Slootman, The use of information and communication technologies by older people with cognitive impairments: from barriers to benefits, "Computers in Human Behavior" 104, 2020, pp. 106-173.

17 Y. Bae., Y. Lee, Socialized soft power: recasting analytical path and public diplomacy, "Journal of International Relations and Development", 23(4), 2019, pp. 871-898.

18 A. Alanazi, Saudi Arabia's implementation of soft power policy to confront Iran's obvious threats (Postdergraduate degree), Naval Postgraduate School Monterey, California, 2015.
} 
results of their implementation. In this case, the quality of management or policy, and the nature of the executive procedures to obtain influence from the use of soft power sources govern the productivity of their use. As for hard power, its use to impose influence does not require the long-term perspective. Rather, it is an achievement or fail immediately after employing and using sources of hard power in a short period of time, as wars may last for days or even years, but in most cases, they end in clear and decisive material results, and the opposite is true to for the application of soft power, which results are evident only over time and through slow accumulation. If the conditions for patience, communication, and sustainability are not met, the use of sources of soft power sources will fail to achieve the desired goals ${ }^{19}$.

\section{THE IMPORTANCE OF SOFT POWER IN INTERNATIONAL RELATIONS}

The most outspoken supporters of soft power mention that its role is to understand the rules of international domination of today's constantly changing world. One of the rules of this game is that post-industrial democracies will be less inclined to use their military power20. As Nye states, because it "is based on luxury rather than glory, and also hates many casualties, the absence of combatant morality in modern democracies means that the use of force requires an ethical justification detailed in elaborate provisions to ensure popular support, unless true survival is threatened". Nye gives the example of the disintegration of the former Soviet Union as a model of a powerful military force was not used at critical moments, stating that "The Soviet Union had terrible military capabilities that pose a threat to Western Europe, and in the early post-World War II period it also had important sources of soft power from the attractiveness of communist ideology and his record against Nazi Germany"21.

However, the USSR squandered a large part of soft power to suppress in domestic and Eastern Europe. The economy did not perform well in subsequent years, despite the increase in military strength. Soviet state-run propaganda and cultural programmes could not compare with the resilience and attractiveness of the US's popular commercial culture. The Berlin Wall was destroyed before it collapsed in 1989. Volha and Andrei mentioned that if Western popular culture had not penetrated the Berlin Wall, hammers and bulldozers would not have destroyed it. Regardless of the importance of the US's military power and political commitment in anchoring successes in Cold War Europe, the truth is that American economy and culture attracted most young people's views on Western democracy. The Cold War was won by a mixture of two forces: hard and soft power. Hard power created a strong military containment wall, but the soft power eroded and disintegrated the Soviet system from inside ${ }^{22}$. The insistence

\footnotetext{
${ }^{19}$ New Power Generation ... The rise of "soft power" and what does it take to be loved in a world of economic and political power plays?, 2019, https://www.peterfisk.com/2019/10/soft-power-super-powers-what-does-it-take-tobe-loved-in-a-world-of-economic-and-political-power-plays/ (13.05.2021).

${ }^{20} \mathrm{G}$. Gallarotti, Soft power: what it, op. cit.

${ }^{21} \mathrm{H}$. Wagner, The Decision to Divide Germany and the Origins of the Cold War, "International Studies Quarterly" 24(2), 1980, p. 155.

${ }^{22}$ F. Fukuyama, The End of History?, “The National Interest” (16), 1989, pp. 3-18.
} 
on the importance of soft power was not born out of a vacuum. Even the critics of soft power did not ignore its importance and influence. The Tunisian politician Rafik Abdel Salam, founder of the Centre for Strategic and Diplomatic Studies in Tunis and London, summarised this matter with several facts, such as: "It has become very familiar that the intellectual, the politician, and even the general public in New Delhi, Cairo, Jakarta, and Beijing see the system of architecture and engineering of cities and streets, the enactment of laws, the playing of music, and perhaps poetry in English, French or American manner as the ideal and perhaps the only model for the development of awareness and the embodiment of civilization" 23 .

A notable sign of soft power is that terrorist organisations, extremist movements, and non-governmental organisations have succeeded in expanding across the borders of states mainly through their soft power; and this matter was noticeable before as "Terrorism depends critically on soft power for its final victory, and it depends on its ability to attract support from the crowd in a way that is at least equivalent to his ability to destroy the will to fight of its enemy" 24 .

"Soft power depends on an audience ready to receive even if the eye of the beholder is evil. Transnational terrorist organizations such as Al Qaeda may be alienating most of the world, but it is clear that they are attractive to some extremists." For non-governmental organisations, they are deflecting the soft power that helps them expand, as "a global conscience represents a broad public interest that transcends the scope of individual states, and governments must take them into account, whether as allies or opponents". These organisations are flexible and effective in penetrating states regardless geographical borders ${ }^{25}$. The danger of soft power in the field of international relations has reached a climax when prominent international leaders spoke warmly about the impact of this power, for example, Ali Khamenei, the Supreme Leader of the Islamic Revolution in Iran, who called on his people to be beware of what he dubbed the soft war of enemies, saying: "The soft war is a real war in our contemporary world, even though some people do not see it." ${ }^{26}$

\section{Soft Power Probability to Be Measured}

The study of soft power confronts various difficulties, the most serious of which is the difficulty of measurement. This contrasts with the traditional material strength, which is easy to measure with metrics involving physical indicators. Hence, treating the components of soft power as a comparative concept depends on the rational and various indicators of measurement. The method used to define and measure soft power indicators in the Global Soft Power Report is considered one of

\footnotetext{
${ }^{23}$ I. Manor, The Irrelevance of Soft Power, "E-International Relations", 2020, pp. 1-6.

${ }^{24}$ H. Pesto, The Role of Diplomacy in the Fight Against Terrorism, "Connections" 10(1), 2010, pp. 64-81.

${ }^{25}$ K. Feste, America Responds to Terrorism, 2011, pp. 49-80.

${ }^{26}$ See: K. Sadjadpour, Reading Khamenei: The World View of Iran's Most Powerful Leader, Washington 2009.
} 
the best achievements so far $^{27}$. Soft power indicators are divided into two categories in terms of the nature of each of them and how they are measured ${ }^{28}$ :

1. The first group consists of objective components, with a relative weight of $70 \%$ on the soft power general index, including government, digital, culture, initiatives in enterprise projects, interaction and engagement, and education.

2. The second group is an ethical component, which is evaluated based on a survey of expert opinions in each field. The relative weight of the soft power composite index is 30\%, including: moral components based on opinions and polls (with a relative weight of 30\%), and include: culinary culture and ethnic cuisine, technological products, culture, abundance of luxury goods, and liveability.

\section{SOURCES OF SofT PoWer}

Currently, the field of competition and conflict between countries are no longer only in the realm of traditional military force. The new battlefield has become the ideology, economy, technology, knowledge, and competence in managing the state's domestic resources and in defending its international interests and those who negotiate on its behalf in the field of foreign policy, economy and international trade. Other areas are equally important, such as media, culture, justice, and various forms of internal security. People are the cornerstone; they are the soft power of any state with the capabilities and competence, especially those who are assigned to take over power in the sensitive areas of the country. This includes ministers, secretaries of ministries, general directors, ambassadors, and negotiators acting on behalf of the state in international forums ${ }^{29}$. Countries are keen to ensure that nominees in these areas are people with high potential, chosen according to precise standards of competence rather than those of social and private relations. This has concentrated and strengthened the country's soft power and its efficiency of managing its resources30. There is much evidence that countries with smaller populations, territories, and economic resources have surpassed others thanks to the virtue of their soft power and efficiency in managing national resources. On the contrary, some important and pivotal countries have weakened and withdrawn due to the dominance of a certain group over the state, or because of factional and sectarian parties. The sources of soft power are not limited to human beings, but also include the natural assets owned by the country such as cultural and historical heritage, social institutions, well-known companies, and brands. China for example, has recently become famous in the world thanks to its trademark Huawei, rather than its conventional military strength.

\footnotetext{
${ }^{27}$ Y. Seong-Hun, An Overdue Critical Look at Soft Power Measurement: The Construct Validity of the Soft Power 30 in Focus, "Journal of International and Area Studies" 25(2), 2018, pp. 1-20.

${ }^{28}$ J. Mcclory, A Global Ranking of Soft, op. cit.

${ }^{29}$ K. Yavuzaslan, M. Cetin, Soft Power Concept and Soft Power Indexes, "Business Challenges in The Changing Economic Landscape" 1, 2016, pp. 395-409.

${ }^{30}$ D. Rutkowski, L. Engel, Soft Power and Hard Measures: Large-Scale Assessment, Citizenship and the European Union, "European Educational Research Journal” 9(3), 2010, pp. 381-395.
} 


\section{Soft Power Has Important Advantages}

Soft power not only embodies the power of governments, but also the power of their people, which makes the country responsible for creating well-organised governments, management, and decision-makers. It also requires people to make unremitting efforts for cultural development in the fields of higher and popular culture as responsibility. The attractiveness of the soft power model requires the state to persuade people that its domestic and foreign policies are correct, which means that repulsive and hateful policies will not be welcomed by those who want to have a high impact in terms of soft power ${ }^{31}$.

Soft power is not a blind force, although it is intangible; because it conforms to the understanding of changes in the international environment, adapts to these variables and prepares to compete with its influential participants, and to achieve the desired results for the country in a wise manner. However, weakness - both outwardly and fundamentally - is unacceptable, because the weak can be suppressed by soft power militarily and economically. Whoever wants to win in the highly complex and competitive international environment must not only be strong, but the government must also be accepted by all parties by culture, effective policies, advanced technology, and influential institutions. The effective use of this force helps to contain destructive intellectual tendencies, extremist movements, and aggressive states by the concerted effort of international will, which genuinely desires to achieve international peace and security. Conversely, when they are abused or when they do not possess their sources ${ }^{32}$.

\section{The STRATegic Employment OF Soft PoWer}

Joseph Nye believed that there are two fundamental power shifts in the twenty-first century. One is the shift between nations from West to East, which can be called the recovery of Asia. The second is the distribution of power from all Western countries to non-state parties, as a result of the extremely low cost of computing and communications operations caused by the current information revolution. Essentially, this has enabled non-state actors and individuals to do things that were previously restricted to governments or large institutions. The second change in power affects the concept of soft power and its components in some way. Because the power that non-states possess is, in most cases, the soft power of extremist groups and other groups; especially in the field of media deployment, religious affiliation, the use of the Internet and social media, the possibility of addressing extremists in multiple languages, and the use of

\footnotetext{
${ }^{31}$ J. Nye, The Benefits of Soft Power, 2014, https://hbswk.hbs.edu/archive/the-benefits-of-soft-power (13.05.2021).

32 J. Klabbers, Intervention, Armed Intervention, Armed Attack, Threat to Peace, Act of Aggression, and Threat or Use of Force, Oxford Handbooks 2016.
} 
technology, computing, and other information technologies. The use of soft power by these groups has not been challenged by many countries. The best example is that Arab countries, especially those with unstable political situations, such as Iraq, Syria, and other unstable states, which have witnessed the so-called Arab Spring. Today, these countries have a real need to rejuvenate themselves and at least apply their soft capabilities to compete with non-state extremist groups. Overcoming these groups requires the correct use of soft power resources rather than military and economic power, or hard power ${ }^{33}$.

The image and attractiveness of countries depend greatly on the strength of their domestic and international values and policies. Meanwhile, this image does not only enhance the country's external strength but also reinforces its internal strength by bolstering the citizen's confidence in themselves and the political system. And when "you have a political system with specific characteristics and defend higher human values that turns into a model. This model can inspire others to emulate it; and the state, under its model, turns into an effective player in the international arena" 34 .

In the last century, Hollywood fought against Nazism, socialism, communism, and ultimately terrorism, at the same time promoting capitalism and individualism. The US has established its image in the eyes of the world, by highlighting itself as a symbol and a model of values, especially those of democracy, freedom, social justice, respect for individuality, and individual freedom. Therefore, Hollywood can play a fundamental role in policy-making and finding solutions via its soft power. Ian Scott mentioned in his book The American Policies in Hollywood Movies that "These films gradually succeeded in shaping the democratic and institutional agenda of the United States of America" 35 . In other words, as Peter Rollins pointed out, Hollywood produced films consciously to change public opinion trends towards political and social matters, which attacked American cinema - influenced by political trends - such as fascism, Nazism, communism, and terrorism. Thus, the film industry has led Americanism and traditionally played an important role in spreading American popular culture and attracting sympathy for the American style of life, as well as presenting an attractive model for American values, especially those of freedom, individuality, and movement ${ }^{36}$.

The policymakers in the Middle East realised that the country cannot only rely solely on hard power to achieve their goals but also need to develop other types of power such as the power of culture, thoughts, educational institutions, the effectiveness of domestic policies, and the nature of values reflected in foreign policy. The state's positive glow in the eyes of others is not a secondary matter, rather it is an important basis for persuading them to voluntarily

\footnotetext{
${ }^{33} \mathrm{C}$ Gray, Hard Power and Soft Power: The Utility Of Military Force as an Instrument of Policy in the 21st Century, Strategic Studies Institute, US Army War College, 2011.

${ }^{34}$ International Political Science Abstracts, 70(4), 2020, pp. 479-632.

${ }^{35}$ I. Scott, American Politics in Hollywood Film. Edinburgh University Press, Edinburgh 2011.

${ }^{36}$ Ibidem.
} 
submit to what we desire to achieve. It is essential to motivate others effectively by accepting what you put on the agenda and making them feel respected and influenced by your model ${ }^{37}$.

Soft power is inaccessible in international relations and national security policies, and the outcomes are demoralising and difficult for the same reason. It may take several generations to achieve moral strength and it may take one year or more to achieve physical strength. Since the end of World War II, people witnessed the devastating bombing of Hiroshima and Nagasaki in Japan, many world political scientists and policymakers have realised that the use of nuclear weapons to achieve or expand influence on a global scale has become almost impossible. Although the US considers modernising its nuclear arsenal by producing small or ultra-small nuclear weapons, policymakers in Washington may soon realise that this option will lead to widespread condemnation worldwide, because, whether it is wrought with small or large bombs, it will open the door to a new wave of human destruction. Since the end of World War II, nuclear weapons production has exceeded the bounds of ethical standards, and the author does not think this situation will change ${ }^{38}$.

Thus, political scientists and policymakers are urged to study the use of other means to achieve influence and control. In the beginning, George Kennan presented the theory of containment; about a quarter of a century later, Joseph Nye proposed the theory of soft power, which states that an enticement, not war, threat, and coercion, can be implemented to dictate the achievement of influence expansion39. Since Nye in 1991 proposed his theory until the present, this theory has developed and is influencing the changes across the world. Nye concluded that the balance of power in the world is experiencing profound changes, the most important of which is the shift of the axis of power to the East, and the gradual shifting of the sources of power from the country to new partners in international relations. The most important of these are multinational companies, national, regional, or global armed or unarmed non-governmental organisations, and non-governmental organisations of a global nature, such as Amnesty International, Greenpeace, and others ${ }^{40}$. Recently, the Kingdom of Saudi Arabia has been interacting with centres of gravity and influence in international politics, considering all implications and responsibilities of this policy. In this context, the Kingdom is proud to be one of the founding members of the United Nations (which was established in 1945), based on its deep belief that world peace is a goal of its foreign policy. Therefore, Saudi foreign policy depends primarily on the influential dimension of soft power, which is defined as attracting and influencing the regional environment by presenting an attractive model to follow. Before Iranian politics posed threats, the Kingdom had overcome all surrounding threats by focusing on the patterns of soft power in the face of the rivalry of hard and soft power. As a result,

\footnotetext{
${ }^{37}$ I. Lustick, The Absence of Middle Eastern Great Powers: Political "Backwardness" in Historical Perspective, "International Organization" 51(4), 1997, pp. 653-683.

${ }^{38}$ J. Winkler, J. Nye, Soft Power: The Means to Success in World Politics, "International Journal” 61(1), $2005, \mathrm{p} 268$.

39 J. Iatrides, George F. Kennan and the Birth of Containment: The Greek Test Case, "World Policy Journal" 22(3), 2005, pp. 126-145.

${ }^{40}$ J. Nye, Is the American Century Over? "Political Science Quarterly" 130(3), 2015, pp. 393-400.
} 
the Nationalism and Nasserism are the most obvious examples of the ability of soft power to marginalise and weaken solid or hard power ${ }^{41}$.

\section{CONCLUSION}

The Kingdom of Saudi Arabia adopts and launches soft power theoretically and practically. Hence, the model of soft power, its influence, and attractiveness is the most effective model in our society. It is applicable to the political, social, and cultural, which requires investment in our transformative projects and renewal developments in political, economic, social, and cultural realms.

The Saudi economy has a global influence and contributes to the most important international economic institutions, including the International Monetary Fund, the World Bank, and the Islamic Development Bank. The Kingdom can contribute to directing the global economy via these institutions, and this is an important soft power. Moreover, Saudi diplomacy has a global presence and influence that pursues moderation and is keen on international peace, security, and good neighbourliness. It is a soft power that has contributed to many situations, especially in neighbouring countries, including the historic peace between Ethiopia and Eritrea $^{42}$. The Kingdom of Saudi Arabia has become the pioneer in eradicating terrorism by the establishment of a centre (Global Center to Combat Extremism - Etidal) to prevent and fight recruitment in cyberspace; which is the soft power at the level of world security.

The 2030 vision proposed by His Royal Highness Prince Mohammed bin Salman, Crown Prince of Saudi Arabia, includes three strong pillars of the Kingdom of Saudi Arabia. Once implemented, they will create effective soft power in many areas and will change the world's view of the Kingdom. Since the implementation of Vision 2030 Project, the Kingdom has made a great change in its global stereotype. The most important aspects are fighting corruption, raising the level of transparency from the government to citizens, empowering Saudi women in the labour market, and enabling them to participate in the process of building the country even at the political level, as two of them have been appointed as ambassadors to the US and Norway, and one has become a member of the Shura Council ${ }^{43}$.

Soft power is important but also elusive. It is unlikely to exist in the absence of an adequate measure of economic success, an efficient political apparatus, and a regulatory framework that leads society. The world today is rapidly changing, and those who are willing to become more advanced in technology and economy need to be open to others. Soon, the effects of soft power will increase in a way unprecedented in human history to make all

\footnotetext{
${ }^{41}$ See: M. Mayer, M. Carpes, R. Knoblich, The Global Politics of Science and Technology - Vol. 1. Concepts from International Relations and Other Disciplines, Springer 2014.

${ }^{42}$ M. Haque, The Growth of Private Sector and Financial Development in Saudi Arabia, "Economies" 8 (2), 2020, p. 39.

43 S. Grand, K. Wolff, Assessing Saudi Vision 2030: A 2020 review - Atlantic Council, 2020 , https://www.atlanticcouncil.org/in-depth-research-reports/report/assessing-saudi-vision-2030-a-2020-review/ (13.05.2021).
} 
countries and societies be more interconnected. As a result of the sources of their soft power, the weakest countries will find that they are besieged day after day until they reach one of the two outcomes. Either they will develop special soft power sources that enable them to constantly compete and influence others, or they will be defeated, losing the support from their societies.

\section{BIBLIOGRAPHY}

Alanazi Abdullah Khuliyf. 2015 Saudi Arabia's implementation of soft power policy to confront Iran's obvious threats (Postdergraduate degree). California: Naval Postgraduate School Monterey.

Bae Yooil. Lee Yong Wook. 2019. "Socialized soft power: recasting analytical path and public diplomacy". Journal of International Relations and Development. 23(4): 871-898. doi: 10.1057/s41268-019-00169-5.

Bates Thomas. 1975. "Gramsci and the Theory of Hegemony". Journal of The History of Ideas. 36(2): 351. doi: 10.2307/2708933.

Behrent Michael. 2014. "Foucault and Technology". History and Technology. 29(1): 54-104. doi: 10.1080/07341512.2013.780351.

Blok Marije. van Ingen Erik. de Boer Alice. Slootman Marieke. 2020. "The use of information and communication technologies by older people with cognitive impairments: from barriers to benefits". Computers in Human Behavior. 104: 106173. doi: 10.1016/j.chb.2019.106173.

Feste Karen. 2011. America Responds to Terrorism. Palgrave Macmillan.

Fukuyama Francis. 1989. The End of History? The National Interest. Free Press.

Gallarotti Giulio. 2011. "Soft power: what it is, why it's important, and the conditions for its effective use". Journal of Political Power. 4(1): 25-47. doi: 10.1080/2158379x.2011.557886.

Gomichon Maxime. 2021. Joseph Nye on Soft Power. https://www.eir.info/2013/03/08/joseph-nye-on-soft-power/.

Górnikiewicz Marcin. Bielawski Radosław. Walkowiak Marzena. 2020. "Russian "Hard Power" and "Soft Power" in Influencing Central and Eastern European Countries on the Example of Poland in the COVID-19 Era". International Journal of Economics and Business Administration. Volume VIII. Special Issue 3: 18-26. doi: 10.35808/ersj/1849.

Grand Stephen. Wolff Katherine. 2020. Assessing Saudi Vision 2030: A 2020 review - Atlantic Council. https://www.atlanticcouncil.org/in-depth-research-reports/report/assessingsaudi-vision-2030-a-2020-review/.

Gray Colin. 2011. "Hard Power and Soft Power: The Utility Of Military Force as an Instrument of Policy in the 21st Century". Strategic Studies Institute. US Army War College.

Haque Mohammad Imdadul. 2020. "The Growth of Private Sector and Financial Development in Saudi Arabia". Economies. 8(2): 1-15. doi: 10.3390/economies8020039.

Harris Trevor. 2018. "Foreign policy in an age of austerity: 'soft power', hard choices". Observatoire De La Société Britannique. (20): 17-36. doi: 10.4000/osb.1976.

Holsti Kalevi Jaakko. 1964. "The Concept of Power in the Study of International Relations". Background. 7(4). doi: 10.2307/3013644.

Howard Michael. 1976. “The Strategic Approach to International Relations”. British Journal of International Studies. 2(1): 67-75. 
Iatrides John. 2005. "George F. Kennan and the Birth of Containment: The Greek Test Case". World Policy Journal. 22(3): 126-145.

International Political Science Abstracts. 2020. 70(4): 479-632. doi: 10.1177/0020834520948971.

Ketbi Ebtesam. 2020. "Contemporary Shifts in UAE Foreign Policy: From the Liberation of Kuwait to the Abraham Accords". Israel Journal of Foreign Affairs. 14(3): 391-398. doi: 10.1080/23739770.2020.1845067.

Klabbers Jan. 2016. "Intervention, Armed Intervention, Armed Attack, Threat to Peace, Act of Aggression, and Threat or Use of Force". Oxford Handbooks. doi: 10.1093/law/9780199673049.003.0023.

Lustick Ian. 1997. "The Absence of Middle Eastern Great Powers: Political "Backwardness" in Historical Perspective". International Organization. 51(4): 653-683.

Manor IIan. 2020. "The Irrelevance of Soft Power”. E-International Relations: 1-6.

Mayer Maximilian. Carpes Mariana. Knoblich Ruth (ed.). 2014. The Global Politics of Science and Technology - Vol. 1. Concepts from International Relations and Other Disciplines. Springer. doi: 10.1007/978-3-642-55007-2.

McClory Jonathan. 2019. A Global Ranking of Soft Power. https://softpower30.com/wpcontent/uploads/2019/10/The-Soft-Power-30-Report-2019-1.pdf.

Nye Joseph. 1990. "Soft Power". Foreign Policy. (80). doi: 10.2307/1148580

Nye Joseph. 2014. The Benefits of Soft Power. https://hbswk.hbs.edu/archive/the-benefits-ofsoft-power.

Nye Joseph. 2015. “Is the American Century Over?”. Political Science Quarterly. 130(3): 393-400.

Ooi Can-Seng. 2015. "Soft power, tourism”. Encyclopedia of Tourism: 1-2. doi: 10.1007/9783-319-01669-6_184-1.

Özgün Erler Bayir. 2016. "Challenges for EU in the Middle East: Use of Soft Power”. Studia Europejskie-Studies in European Affairs. 2: 9-19.

Pesto Haris. 2010. "The Role of Diplomacy in the Fight Against Terrorism”. Connections. 10(1): 64-81.

Peter Fisk. 2019. New Power Generation ... The rise of "soft power" and what does it take to be loved in a world of economic and political power plays?. October 15, https://www.peterfisk.com/2019/10/soft-power-super-powers-what-does-it-take-to-beloved-in-a-world-of-economic-and-political-power-plays/

Rutkowski David. Engel Laura. 2010. "Soft Power and Hard Measures: Large-Scale Assessment. Citizenship and the European Union". European Educational Research Journal. 9(3): 381-395. doi: 10.2304/eerj.2010.9.3.381.

Sadjadpour Karim. 2009. Reading Khamenei: The World View of Iran's Most Washington: Powerful Leader.

Satell Greg. 2011. Our World Turned Upside Down Digital Tonto. https://digitaltonto.com/2011/our-world-turned-upside-down/.

Scott Ian. 2011. American Politics in Hollywood Film. Edinburgh: University Press.

Seong-Hun Yun. 2018. "An Overdue Critical Look at Soft Power Measurement: The Construct Validity of the Soft Power 30 in Focus". Journal of International and Area Studies. 25(2): 1-20. doi:10.2307/26909941. 
Wagner Harrison. 1980. "The Decision to Divide Germany and the Origins of the Cold War". International Studies Quarterly. 24(2). doi: 10.2307/2600199.

Wagner Jan Philipp. 2014. "The Effectiveness of Soft \& Hard Power in Contemporary International Relations”. E-International Relations. https://www.e-ir.info/2014/05/14/the-effectiveness-ofsoft-hard-power-in-contemporary-international-relations/.

Winkler John. Nye Joseph. 2005. "Soft Power: The Means to Success in World Politics". International Journal. 61(1). doi: 10.2307/40204149.

Yavuzaslan Kiymet. 2016. "Cetin Murat, Soft Power Concept and Soft Power Indexes". Business Challenges in The Changing Economic Landscape. 1: 395-409 doi: 10.1007/978-3-319-22596-8_28. 